\title{
Strategic Analysis of Independent Institute Students' Employment Difficulties and Career Planning
}

\author{
Lin Jing \\ Sub-Institute of Science Technology and Art, Jingdezhen Ceramic Institute, Jingdezhen, Jiangxi, China
}

Keywords: College students; Career planning; Independent institute personnel training mode; Reform

\begin{abstract}
In the face of the problem of employment difficulties for college students, especially for independent institute students, career planning for college students can alleviate the problem, and increase the proportion of independent institute graduates with successful career. In this paper, based on analysis of the correlation between career planning of independent institute graduates and independent institute talent cultivation, combined with the issue of employment difficulties in current society, a specific thinking over the reform mode of career planning for college students in line with the requirements of independent institute talent cultivation was carried out, aiming to better achieve college students' employment target.
\end{abstract}

\section{Introduction}

Robot World Cup [1][2] is a form of football, through the competition to test new technologies in order to promote artificial intelligence, robotics and development projects of related areas; meanwhile, it also provides a broad platform to the robot hardware, software technology research. Robot soccer game is put forward in recent years of multi-agent system development platform, and it is a typical multi-agent robotic System. Soccer robot design has become the artificial intelligence and robotics research in the one of the hotspots field [3].

Career planning is an action orientation and action plan made by individuals based on their own conditions and constraints to achieve the career goal and to avoid the blindness of employment. In the environment with fierce social competition, independent institute students should plan their career well in advance, and capture the career development direction conforming to their practical situation ahead of time, thereby improving their chances of employment and achieving success of personal development. Therefore, the personnel training mode of present independent institutes needs to actively include the content of career planning for college students.

\section{The importance of career planning for independent institute students}

(1) The importance of college students' career planning for their individual development

Firstly, career planning for college students is the requirement of social and economic development. In the environment with fierce employment, if students did not make career planning suitable for themselves, thoughtlessness will occur in their job hunting. At the same time, in the absence of career planning, students' employment targets are limited to wages, and whether their job selection conforms to personal characteristics is not taken into consideration. Secondly, the deployment of college students' career planning in advance can effectively help graduates complete their career and life planning and individual vision. The career planning of college students is concerned with their self-cognition, and can help the students to realize scientific positioning of life planning. Thirdly, career planning for college students can help the students further clarify their life goals. The early cognition and strict deployment of career planning can effectively help the students to achieve their career goals as early as possible, and provide explicit thinking and strategy support for the career development of independent institute students.

(2) The importance of college students' career planning for talent training mode of independent 
institutes

The common points between college students' career planning and the talent training mode of independent institutes are specifically embodied in the following aspects: first, the commonality between development goals. The talent training mode of colleges consists of teaching and learning, thereinto, teaching is reflected by the supply of faculty and the teaching level, and learning is reflected by the learning consciousness and objectives of students. In this research, through a whole set of rigorous and complete evaluation system, independent institute students were helped to accurately and effectively set career development goals in advance, so as to achieve integrated development. Second, practices can supplement. At present, high school teaching has very strong theoretical property, and cultivation of knowledge application ability is relatively few, resulting in disharmony between high school talent training and demand of social development. Career planning for college students lays emphasis on the combination of theoretical knowledge and practical experience, and effectively compensates for the limitations of high school talent training mode. Third, the effect is persistent. High school education and teaching and students' learning are long-term processes, and the acquisition of knowledge points is also a cyclic process. Career planning for college students is a kind of professional practice carried out based on knowledge, it plays a vital function in helping the students to realize self-esteem and to grasp the essence of learning, and besides, it possesses the characteristic of persistence, just like the talent training mode of independent institutes.

\section{Analysis of independent institute students' employment difficulties}

In recent years, higher education has been transformed from elite style to popular style. Colleges and universities are expanding enrollment, and the increase of the number of students has aggravated the problem of college students' employment difficulties, which is especially prominent in independent colleges. In this context, one of the objectives of high school talent training is to improve the social employment rate of the students. The key to the promotion of the possibility for college students' employment is to carry out self-promotion using proper methods in job hunting. College students' career planning has taught the students the way of self-promotion, and can provide technical support for the students' self-promotion. With the continuous development of higher education, the goals of students attending colleges have been gradually unified into finding a good job, however, the social demand for employees in each work is limited, and the continuously expanding of enrollment has triggered the conflict between the large number of college students and limited employment positions in society. In addition, due to people's understanding of "popular majors" and "less popular majors", few students select some of the majors in colleges, while for other majors, serious incompatibility between the required students and the actual registration students appears. With the continuous development and progress of the society, the demand for talents in the employment market has presented the characteristic of diversification, and "popular majors" and "less popular majors" have become relative concepts, hence, under the guidance of the original employment concept, it is difficult for the students to find jobs suitable for them.

\section{Strategies for independent institute students' career planning}

(1) Career planning guidance courses set in colleges to strengthen career education for students

College students' career planning should develop with the practical situation of the students. Based on the talent training requirements in present universities, the career planning guidance courses should achieve the following goals: first, to enhance students' individual and group career planning and decision-making abilities; second, to strengthen the guidance for students to better learn the true self and clarify the trend of vocational values; third, to help the students make career planning decisions by the mastered information; fourth, to help the students better stimulate the development potential and realize life value. The common characteristics of students' personal development should be based to develop a set of planning with guiding significance.

Career guidance planning for college students is a long-term service work, which runs through 
the overall process of students' learning and plays an important role in guiding the students' employment. Therefore, college teachers need to explain the curriculum to students at enrollment, and guide the students to carry out a series of learning according to their career planning.

(2) Support for the implementation of career planning through the reform of various systems

First, the high school enrollment system should be reformed, and the talent training plan and curriculum system should be improved. At enrollment, colleges should provide students with the right to select major, thus enhancing the students' social competitiveness through the independent choice of the major. First of all, the system of selecting major after enrollment should be established, so that the students can select the appropriate major based on their understanding of the school curriculum and their favorite curriculum after a period of time. Besides, the credit system should be implemented. Through the implementation of the credit system, the selection autonomy of students' learning content and the flexibility of making learning plan can be realized. Second, the tutor responsibility system should be improved. The credit system has strong autonomy and randomness, so on this basis, the tutor responsibility system needs to be further improved, through which the students can be further guided to select the appropriate major according to their practical truth, so as to improve the learning effect. At the same time, under the guidance of tutors, students can formulate and modify their learning plan, determine the learning content related to the selected curriculum, and achieve targeted learning.

(3) Flexible career planning platform built for college students

The career planning education for college students needs to be carried out based on rich practical experience, so that college students can enhance their knowledge application ability and personal skills on the basis of self-cognition and environmental cognition. Applicative colleges can build career planning service institutions and information platforms for students inside the schools, and actively help the students to solve various puzzles and problems encountered in making career planning. Furthermore, the abilities of self-management and evaluation of college students should be further cultivated, thereby realizing the conscious and independent development of the students.

\section{Conclusion}

To sum up, college students' career planning has played an important role in promoting talents training of independent institutes. In the present market competition environment, in order to enhance college students' employment rate, colleges and universities should actively build and improve the system and platform of career planning for college students, and the career planning should be included into independent institutes' talents training work, thus cultivating more highly qualified talents for social development.

\section{Acknowledgements}

In this paper, the research was sponsored by Jiangxi Province Social Science Planning Project (special project of foreign language) - the application of nil equivalence translation theory in the practices of ceramic business English translation (serial number: 15WX218); scientific research project of national universities foreign language teaching - the application of nil equivalence translation theory in ceramic cultural creative industrial practices from the perspective of globalization (serial number: Jiangxi-0012-A).

\section{References}

[1] Chen Zhiwei. Discussion on the role of surveying and mapping geographic information in the construction of smart city [J], Jiangxi Building Materials, 2017,(15):230+235.

[2] Zhang Bing, Wan Yumei. Analysis of the role of surveying and mapping geographic information in promoting the construction of smart city [J], Heilongjiang Science and Technology Information, 2017,(16):18. 
[3] Xu Xiali. The role of surveying and mapping geographic information in the construction of smart city [J], Digital Communication World, 2017, (06): 143-145.

[4] Cui Tiejun. The role of geographic information science in the construction of smart city [J], Journal of Tianjin Normal University (natural science edition), 2017,37 (03): 47-53.

[5] Cheng Jun. Brief exploration of the role of surveying and mapping geographic information in the construction of smart Dalian [J], Building Materials and Decoration, 2017, (17): 201-202. 